\title{
THE EXCRETION OF PORPHYRINS IN CONGENITAL PORPHYRIA
}

\author{
By KONRAD DOBRINER, W. H. STRAIN, H. GUILD, and S. A. LOCALIO \\ (From the Department of Medicine, The University of Rochester School of Medicine andi \\ Dentistry, Rochester, New York; The Harriet Lane Home, Johns Hopkins \\ Hospital, Baltimore; and The Hospital of the Rockefeller \\ Institute, New York City)
}

(Received for publication July 22, 1938

In 1915 Hans Fischer identified the kinds and types of porphyrins excreted in congenital porphyria $(1,2,3)$, and since that time 8 cases of this rare disease have been studied by qualitative, chemical methods (4 to 11 ). No quantitative studies of the total excretion of porphyrins in this condition have been made, however, and although reports of the therapeutic effect of liver extract on acute porphyria are recorded in the literature $(12,13,14)$, complete detailed observations have not been published. In this communication qualitative studies of the types and kinds of porphyrins excreted in 3 cases of congenital porphyria are recorded, together with quantitative studies of the coproporphyrin excretion and the effect of liver extract therapy on that excretion in 2 of the cases.

The methods used for the qualitative and quantitative determinations of the urinary and fecal porphyrins, except uroporphyrin, are those previously reported $(15,16)$. Uroporphyrin was isolated by the method of Fischer and Duesberg (11), but because of the lack of a suitable method it was not measured quantitatively. In all instances a thorough search for isomeric and hitherto undescribed porphyrins was made.

The clinical material studied was as follows: Case I (Rochester) (20). A clinical report has been published (29). Case II (Baltimore), Hospital record number 98673, Harriet Lane Home, Johns Hopkins Hospital. Case III (San Francisco). A preliminary report concerning the photosensitivity in this child has already been published by Blum and Hardgrave (17).

\section{RESULTS}

\section{Qualitative}

In all 3 cases both coproporphyrin and uroporphyrin were present in large amounts in the urine. Much coproporphyrin was present in the feces, as well as relatively small amounts of protoporphyrin and deuteroporphyrin. In Table I the results of the melting point determinations

TABLE I

Melting points in ${ }^{\circ} C$. of the porphyrin methyl esters

\begin{tabular}{|c|c|c|c|c|c|}
\hline & \multirow{2}{*}{ Case number } & \multicolumn{2}{|c|}{ Urine } & \multirow{2}{*}{$\begin{array}{l}\text { Feces. } \\
\text { Copro I }\end{array}$} & \multirow{2}{*}{$\begin{array}{c}\text { Free cop } \\
\text { ropor- } \\
\text { phyrin } \\
\text { of } \\
\text { natural } \\
\text { ester }\end{array}$} \\
\hline & & Copro I & Uro I & & \\
\hline II & $\begin{array}{l}\text { (Rochester)...... } \\
\text { (Baltimore)...... } \\
\text { (San Francisco)... }\end{array}$ & $\begin{array}{l}250 \\
251 \\
249\end{array}$ & $\begin{array}{l}286 \\
285 \\
279\end{array}$ & $\begin{array}{l}249 \\
250\end{array}$ & 251 \\
\hline
\end{tabular}

are given. In Case I relatively large amounts of a natural coproporphyrin ester $(15 b)$ were present both in the urine and in the feces, but it was not found constantly. This natural ester had an $\mathrm{HCl}$ number of 0.3 to 0.5 per cent $\mathrm{HCl}$, and was easily extracted from this $\mathrm{HCl}$ concentration with chloroform. It could be saponified with 20 per cent $\mathrm{NaOH}$. After saponification the porphyrin was no longer soluble in chloroform and showed all the properties of coproporphyrin. Spectroscopically it was identical with coproporphyrin. Although the esterifying group could not be established definitely, certain qualities suggested that it was of a lipoidal nature. The Liebermann-Burchard reaction was negative. After saponification the porphyrin was esterified and the methyl ester was identified by melting point determinations as coproporphyrin I (M. P. $251^{\circ}$ C.).

\section{Quantitative}

In Cases I and II quantitative determinations of coproporphyrin excretion in the urine and feces could be made during control periods and during periods of intensive intramuscular liver extract therapy.

Case I (Rochester) Figure 1. A 3-year-old, female child was admitted to the Strong Memorial 


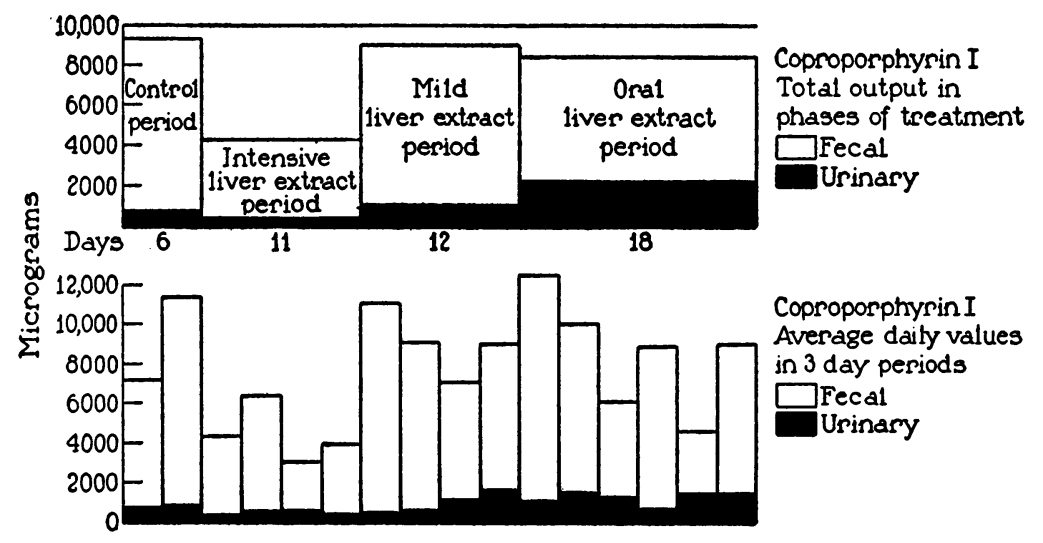

Fig. 1. CASE I

Hospital, Rochester, New York, in August, 1936, and was maintained on a meat free diet during the study. Quantitative studies of coproporphyrin were made both of the urine and feces on 3-day collections. A control period of 6 days was followed by a period of 11 days, during which $5 \mathrm{cc}$. of concentrated liver extract (Eli Lilly and and Co.) was injected intramuscularly each day. In a subsequent period of 12 days, $5 \mathrm{cc}$. of liver extract was administered twice weekly, and in a final period of 18 days 10 to 30 grams of liver extract (Lilly) was administered daily by mouth.

The total excretion of coproporphyrin during the control period was about 50 times the normal average for a child. The average daily total output was 9380 micrograms, of which 870 micrograms were excreted in the urine. Following daily injections of liver extract the total coproporphyrin output decreased to an average of 4450 micrograms a day, of which 550 micrograms were in the urine. In the third period the excretion of coproporphyrin increased rapidly, approaching the levels present before treatment. The total coproporphyrin output during this period averaged 9250 micrograms, of which 1060 micrograms were excreted in the urine. In a fourth period, of 18 days' duration, the patient received from 10 to 30 grams daily of liver extract by mouth, and 2 injections of intramuscular liver extract weekly. The coproporphyrin output in this period averaged 8890 micrograms of which 1240 micrograms were excreted in the urine. During the period of intensive liver extract therapy the uroporphyrin excretion decreased, and the natural porphyrin ester excreted during the control period could no longer be detected. Clinical improvement was manifested by the disappearance of the vesicular eruption.

Case II (Baltimore) Figure 2. The patient was a 4-year-old girl observed from 1936 to 1938 in the Harriet Lane Home and maintained on a constant diet. The urine and feces were collected in 3-day periods and studied at the Hospital of the Rockefeller Institute. In the control period of 15 days the child excreted an average of 5600 micrograms of coproporphyrin daily, of which 1535 micrograms were excreted in the urine. In the treatment period of 12 days the patient received $5 \mathrm{cc}$. of liver extract (Lederle) intramuscularly each day. The total coproporphyrin excretion decreased to 1650 micrograms daily, of which 520 micrograms were in the urine. In a second control period of 12 days the total average coproporphyrin output rose to 6030 micrograms daily, of which 1670 micrograms were in the urine.

\section{DISCUSSION}

The 3 cases reported showed a mass excretion of coproporphyrin I and uroporphyrin I similar to the 6 cases of congenital porphyria previously described in the literature (1 to 8 ). Two cases of congenital porphyria with a mass excretion of coproporphyrin III also have been described elsewhere $(9,10,11)$. Fischer and Hofmann (18) recently reported that in a restudy of the uroporphyrin fraction of the famous case, Petry, small amounts of uroporphyrin III were isolated from the large uroporphyrin I fraction. Uroporphyrin I was excreted by the cases here re- 


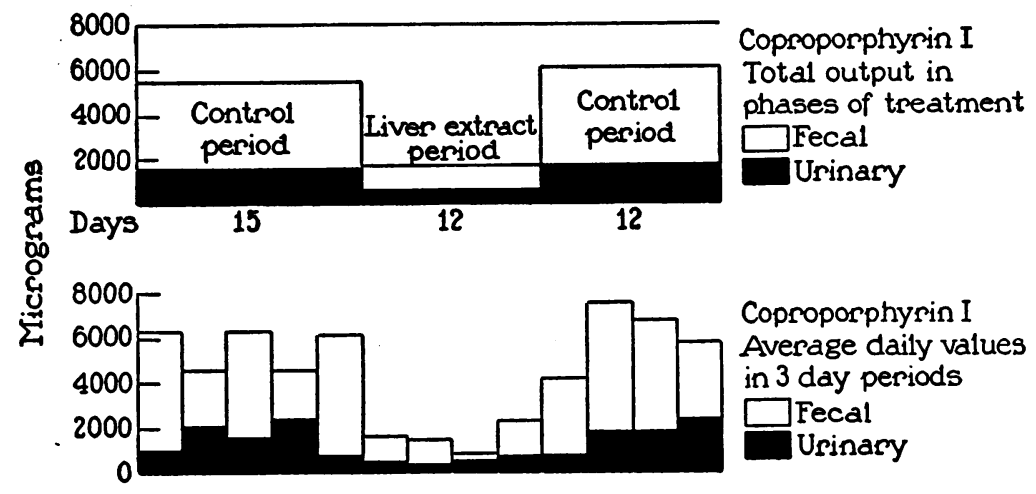

Fig. 2. CASE II

ported, but small amounts of uroporphyrin III may also be present. Work on this phase of the problem is still in progress. The coproporphyrin methyl ester fraction was separated by a method previously described $(15,19)$ and in no instance was coproporphyrin III obtained from the large amounts of coproporphyrin I present.

A working hypothesis which has been outlined previously $(16,20,21,22,23,24)$ is derived from the in vitro synthesis of the porphyrins and is supported by clinical and experimental evidence. The hypothesis postulates the simultaneous construction of Types III and I porphyrins in nature. Under normal conditions there appears to be a relatively constant ratio between the amounts of the 2 types formed.

In congenital porphyria (20) with mass production and excretion of Type I porphyrins the normal ratio between the construction of Type III and Type I compounds is disturbed and a disproportional or disorderly type of synthesis in favor of Type I occurs. In recent publications Rimington independently has come to similar conclusions $(25,26)$. From these studies, together with those previously reported, it appears that the disturbance of porphyrin metabolism which characterizes congenital porphyria is quite unlike that seen in pernicious anemia (23), in pellagra (27), or in refractory anemia (28).

\section{SUMMARY}

1. In 3 cases of congenital porphyria in children qualitative porphyrin studies revealed a mass excretion of coproporphyrin Type I and uroporphyrin Type $I$. In 1 case of the 3 a natural coproporphyrin I ester was excreted.
2. Quantitative studies in $\mathbf{2}$ of the $\mathbf{3}$ cases suggest that the porphyrin excretion in this disease is influenced by daily injections of liver extract.

We are greatly indebted to Dr. W. S. McCann, and Dr. S. W. Clausen for their cooperation and assistance.

\section{BIBLIOGRAPHY}

1. Fischer, H., Uber das Uroporphyrin. I. Ztschr. f. physiol. Chem., 1915, 95, 34.

2. Fischer, H., Utber das Kotporphyrin. II. Uber das Urinporphyrin. Ztschr. f. physiol. Chem., 1915, 96, 148.

3. Fischer, H., and Orth, H., Die Chemie des Pyrrols, 2 (Part I), Leipzig, 1937.

4. Fischer, H., and Zerweck, W., Uber den Harnfarbstoff bei normalen und pathologischen Verhältnissen und seine lichtschützende Wirkung. Zugleich einige Beiträge zur Kenntnis der Porphyrinurie. Ztschr. f. physiol. Chem., 1924, 137, 234.

5. Mackey, L., and Garrod, A. E., A further contribution to the study of congenital porphyrinuria (haematoporphyria congenita). Quart. J. Med., 1926, 19, 357.

6. Ashby, H. T., Haematoporphyria congenita (congenital porphyrinuria); its association with hydroa vacciniforme and pigmentation of the teeth, Quart. J. Med., 1926, 19, 375.

7. Jost, H., Medizinisch-biologischer Abend der medizinischen Fakultät Frankfurt. a. M. Klin. Wchnschr., 1927, 6, 827.

8. Waldenström, J., Studien über Porphyrie. Acta med. Scandinav., Supp. 82, 1937, 22.

9. Van den Bergh, A. A. H., Regniers, and Muller, Ein Fall von kongenitaler Porphyrinurie mit Koproporphyrin in Harn und Stuhl. Arch. f. Verdauungskr., 1928, 42, 306.

10. Fischer, H., Platz, K., and Morgenroth, K., Synthese von Koproporphyrin. III und IV, ein Beitrag zur Kenntnis der Porphyrie. Ztschr. f. physiol. Chem., 1929, 182, 265. 
11. Fischer, H., and Duesberg, R., Uber Porphyrine bei klinischer und experimenteller Porphyrie. Arch. f. exper. Path. u. Pharmakol., 1932, 166, 95.

12. (a) Duesberg, R., Utber die Anämien. II. Anämien und Leberstoff. Arch. f. exper. Path. u. Pharmakol., 1931, 162, 280.

(b) Duesberg, R., Über die biologischen Beziehungen des Hämoglobins zu Bilirubin und Hämatin bei normalen und pathologischen Zuständen des Menschen. Arch. f. exper. Path. u. Pharmakol., 1934, 174, 305.

13. Carrié, C., Experimentelle Untersuchungen zur Hydroa vacciniforme und zur Porphyrinurie. Arch. f. Dermat. u. Syph., 1931, 163, 523.

14. Vannotti, A., Porphyrine und Porphyrinkrankheiten. Berlin, 1937, p. 260.

15. (a) Dobriner, K., Urinary porphyrins in disease. J. Biol. Chem., 1936, 113, 1.

(b) Dobriner, K., Porphyrin excretion in the feces in normal and pathological conditions. J. Biol. Chem., 1937, 120, 115.

16. Dobriner, K., Strain, W. H., and Localio, S. A., I. Quantitative measurement of coproporphyrin and total coproporphyrin I excretion in normals. Proc. Soc. Exper. Biol. and Med., 1937, 36, 752.

17. (a) Blum, H. F., and Hardgrave, L. E., Spectral region of photosensitivity in hydroa aestivale seu vacciniforme with porphyrinuria. Proc. Soc. Exper. Biol. and Med., 1936, 34, 613.

(b) Blum, H. F., and Pace, N., Studies of photosensitization by porphyrins. Brit. J. Dermat. and Syph., 1937, 49, 465.

18. Fischer, H., and Hofmann, H. J., Utber die Konstitution des Uro- und Muschelschalenporphyrins. Nachweis von Uroporphyrin III bei kongenitaler Porphyrie. Ztschr. f. physiol. Chem., 1937, 246, 15.
19. Dobriner, K., Simultaneous excretion of coproporphyrin I and III in a case of chronic porphyria. Proc. Soc. Exper. Biol. and Med., 1936, 35, 175.

20. Dobriner, K., Localio, S., and Strain, W. H., A study of the porphyrins excreted in congenital porphyrinuria. J. Biol. Chem. (Proc.), 1936, 114, xxvi.

21. Dobriner, K., Strain, W. H., Localio, S. A., Keutmann, H., and Stephens, D. I., II. Coproporphyrin I metabolism and hematopoietic activity. Proc. Soc. Exper. Biol. and Med., 1937, 36, 755.

22. Dobriner, K., Excretion of porphyrin by dogs. Proc. Soc. Exper. Biol. and Med., 1937, 36, 757.

23. Dobriner, K., and Rhoads, C. P., The metabolism of blood pigments in pernicious anemia. J. Clin. Invest., 1938, 17, 95.

24. Dobriner, K., and Rhoads, C. P., The excretion of coproporphyrin I following hemorrhage in dogs. J. Clin. Invest., 1938, 17, 105.

25. Rimington, C., Some cases of congenital porphyrinuria in cattle; chemical studies upon the living animals and post-mortem material. Onderstepoort J. Vet. Sci., 1936, 7, 597.

26. Rimington, C., An enzymic theory of haemopoiesis. Compt. rend. d. trav. du lab., Carlsberg, Sér. chim., 1938, 22, 454.

27. Dobriner, K., Strain, W. H., and Localio, S. A., The excretion of porphyrin in pellagra. Proc. Soc. Exper. Biol. and Med., 1938, 38, 748.

28. Dobriner, K., Rhoads, C. P., and Hummel, L. E., The excretion of porphyrin in refractory and aplastic anemia. J. Clin. Invest., 1938, 17, 125.

29. Peachey, C. H., Dobriner, K., and Strain, W. H., Hydroa estivale in congenital porphyria in a case with purplish brown teeth and hirsuties. New York State J. Med., 1938, 38, 848. 